\title{
POTENSI TEMPE PASTA STERIL IRADIASI SEBAGAI NUTRISI ENTERAL PASIEN YANG MENGGUNAKAN ALAT BANTU NASO GASTRIC TUBE (NGT)
}

\author{
POTENTIAL OF RADIATION STERILIZATION TEMPE PASTA AS ENTERAL \\ NUTRITION FOR PATIENTS WITH NASO GASTRIC TUBE (NGT) EQUIPMENT
}

\author{
Zubaidah Irawati' ${ }^{1)}$, R.S. Adji Koesoemowidodo'), Ades Puspita ${ }^{2)}$, Swasono R Tamat ${ }^{2)}$ \\ ${ }^{1)}$ Pusat Aplikasi Isotop dan Radiasi, Badan Tenaga Nuklir Nasional, \\ Jl. Lebak Bulus Raya No. 49 Jakarta-Indonesia \\ ${ }^{2)}$ Fakultas Farmasi-Universitas Pancasila, Srengseng Sawah-Depok, Indonesia \\ Email : irakoenari@yahoo.com
}

Diterima : 19 Agustus 2013, Direvisi : 8 Agustus 2013, Disetujui: 26 September 2013

\begin{abstract}
ABSTRAK
Proses radiasi pada bahan pangan memiliki potensi untuk meningkatkan promosi makanan yang aman, baik, dan sebagai sarana pemasok pangan bergizi untuk rumah sakit. Proses tersebut dapat diterapkan dalam dua segi dalam rangka mendukung aspek kesehatan dan kesejahteraan manusia karena dapat mengeliminasi mikroba patogen penyebab penyakit dan pengawetan pangan karena dapat menghancurkan sumber penyakit. Telah dipelajari pengaruh radiasi pengion terhadap sampel terpilih tempe pasta untuk dikonsumsi pasien yang menggunakan alat bantu Naso Gastric Tube (NGT). Tempe pasta dikemas secara vakum di dalam kantung laminasi poliester- aluminium foil- linear low density polyethylene dan diiradiasi gamma dengan dosis masingmasing $10 \mathrm{kGy}$ dan $25 \mathrm{kGy}$ dalam kondisi beku kemudian disimpan pada suhu kamar selama 6 dan 12 minggu. Pengamatan telah dilakukan terhadap beberapa parameter mutu. Tidak ada perbedaan yang nyata antara sampel pasta yang tidak diiradiasi dengan sampel yang diiradiasi terhadap kadar air, $\mathrm{pH}$, kadar protein, viskositasnya. Disamping itu, kadar isoflavon genestein dan kapasitas antioksidan menunjukkan peningkatan dengan bertambahnya dosis iradiasi setelah sampel disimpan sampai 12
\end{abstract}

minggu. Kadar Malonaldehida tempe pasta menunjukkan peningkatan pula dengan bertambahnya dosis iradiasi dan masa simpan, tetapi bilangan peroksida tidak terdeteksi pada seluruh sampel yang diamati. Tempe pasta pada derajat kekentalan dan ukuran partikel tertentu dapat dipertimbangkan sebagai makanan berbasis protein untuk diberikan kepada pasien imunitas rendah yang menggunakan alat Naso Gastric Tube (NGT).

Kata kunci : Tempe pasta, iradiasi pangan, isoflavon genestin, pangan bernutrisi, pasien imunitas rendah

\section{ABSTRACT}

Food irradiation process has a potential to promote of a safe, adequate and nutritious food supply for hospital diets. It has two applications that can contribute to the health and well being of humanity, i.e. the elimination of foodborne pathogens microorganisms, and the preservation of foods by the destruction of pests. Effects of ionizing radiation on tempe pasta selected as samples for patient food intake through Naso Gastric Tube (NGT) has been studied. Tempe pasta was vacuum packed in a laminate pouch of polyesteraluminum foil- linear low density polyethylene and gamma irradiated at doses of $10 k G y$ and $25 k G y$, respectively 
under cryogenic condition and then stored at room temperature for 6 and 12 weeks.Some quality parameters were observed. There was no significant differences between unirradiated and irradiated tempe pasta on the moisture content, $\mathrm{pH}$, protein content and viscosity. Meanwhile isoflavon genestein content and antioxidant capacity showed an increase by increasing irradiation dose up to 12 weeks of storage. Malonaldehyde content in tempe pasta was accelerating by increasing the irradiation dose and extending the storage period but Peroxide value was not detected in all treated samples. The irradiated tempe pasta at certain degree of viscosity and particle size could be considered as protein base food intake for immunocompromised patients through Naso Gastric Tube (NGT).

Keywords : Tempe pasta, food irradiation, isoflavon genestine, nutritious food, immunocompromised patients.

\section{PENDAHULUAN}

Asupan pangan dengan nutrisi berimbang, higienis dan bermutu tinggi yang diberikan kepada pasien dengan imunitas rendah terdiri dari makanan biasa (nasi dan lauk pauk), makanan lunak (bubur atau tim), makanan saring, dan makanan cair (enteral dan parental). Pada pasien yang mengalami permasalahan asupan nutrisi secara oral dan saluran cerna, biasanya diberikan melalui naso gastric tube (NGT) yang dikenal dengan istilah nutrisi enteral, yaitu pemberian nutrisi melalui saluran cerna dengan menggunakan sonde ${ }^{(1,2)}$.
Manfaat dari pemberian nutrisi enteral antara lain untuk mempertahankan fungsi pertahanan dari usus, mempertahankan integritas mukosa saluran cerna, mempertahankan fungsi-fungsi imunologik mukosa saluran cerna, mengurangi proses katabolik, menurunkan resiko komplikasi infeksi secara bermakna, dan pasien-pasien yang dapat diberikan nutrisi enteral adalah pasien yang tidak mampu mengkonsumsi makanan secara normal. Nutrisi yang diperlukan untuk pasien yang terpasang NGT umumnya mengandung protein, lemak, karbohidrat, mineral, asam lemak, serat, vitamin, yang antara lainjuga terdapat di dalam tempe ${ }^{(1)}$.

Di Indonesia, kedelai dikonsumsi dalam bentuk tempe sebesar 50\%, $40 \%$ dalam bentuk tahu, dan $10 \%$ dalam bentuk produk lain seperti tauco dan kecap. Tempe terbuat dari kacang kedelai yang telah difermentasi dengan kapang Rhizopus atau ragi tempe ${ }^{(3)}$ sehingga dapat menghasilkan produk baru yang lebih mudah dicerna. Tempe juga mengandung senyawa isoflavon aglikon yang berasal dari transformasi kedelai yang mengandung isoflavon glukosida melalui proses fermentasi oleh ragi. Senyawa yang terdapat di dalam tempe antara lain adalah: daidzein (4,7-dihidroksi-isoflavon), genestein (4,5,7-trihidroksi-isoflavon), glistein dan faktor II (4,6,7-tri-hidroksiisoflavon). Senyawa-senyawa tersebut 
diduga mempunyai efek antikanker/antitumor karena bersifat sebagai antioksidan (4). Tekstur tempe yang akan diberikan kepada pasien yang terpasang NGT diubah dalam bentuk pasta agar mudah dalam penyajiannya. Pasta merupakan campuran antara zat padat dengan konsentrasi tinggi ( $>50 \%)$ yang terdispersi dalam bahan dasar berminyak, bukan minyak atau setengah padat ${ }^{(5)}$.

Tempe olahan yang digunakan sebagai sampel penelitian adalah tempe pasta yang akan dikombinasi dengan Medium Chain Triglyceride(MCT) sebagaimana telah dilakukan oleh penulis sebelumnya ${ }^{(6)}$. MCT berfungsi sebagai katalisator guna mempermudah proses cerna dan penyerapan tempe pasta di dalam tubuh. terutama untuk konsumen yang memiliki kendala penurunan daya absorpsi lemak ${ }^{(7)}$. Penelitian ini bertujuan untuk melihat mutu tempe pasta disterilisasi menggunakan proses radiasi pengion agar produk tersebut aman, bersih dan tetap bermutu tinggi selama penyimpanan. Parameter terkait yang akan diamati yaitukadar air, nilai $\mathrm{pH}$, kadar protein kasar, viskositas, dan bilangan peroksida , kadar malonaldehida, kapasitas anti oksidan, dan kadar isoflavon genestine.

\section{BAHAN DAN METODA}

\section{Bahan}

Tempe berumur 36 jam digunakan sebagai sampel yang dibeli dari pengrajin tempe di Bekasi. Medium Chain Triglyceride (MCT) ditambahkan sebagai bahan campuran dibeli dari pemasok bahan penelitian. Bahan pengemas yang digunakan adalah kantung laminasi polyester-aluminium foil-polietilen densitas rendah (LLDPE) yang diperoleh dari industri bahan pengemas di Jakarta Timur. $\mathrm{CO}_{2}$ padat diperoleh dari LAKESPRA SARYANTO, Cawang, Jakarta Timur. Bahan kimia yang digunakan untuk pengujian mutu berkualitas pro analisa (p.a).

Alat

Alat yang digunakan antara lain adalah timbangan analitik Chyo JL-180, pH meter, Labu Kjeldahl, Visconic 20, Spektrofotometer UV mini-1240, dan KCKT Varian 940-LC.

\section{Metoda}

\section{Pembuatan Tempe Pasta}

Tempe pasta dibuat di laboratorium bahan pangan Bidang Proses Radiasi, Pusat Aplikasi Teknologi Isotop dan Radiasi Badan Tenaga Nuklir Nasional (PATIR-BATAN) Pasar Jum'at Jakarta Selatan. Pembuatan tempe pasta sebagai sampel penelitian sampai siap diiradiasi dan disimpan, dilakukan melalui tahapan sebagai berikut: 
Sebanyak $3 \mathrm{~kg}$ tempe dipotong kotak 1x1 cm, lalu direbus selama 5 menit, kemudian dimasukkan kedalam lemari es pada suhu $5 \pm 2{ }^{0} \mathrm{C}$ hingga beku, kemudian ditambahkan $1800 \mathrm{ml}$ air matang dan diblender hingga halus. Setelah campuran tersebut halus, ditambahkan $450 \mathrm{ml}$ minyak MCT, kemudian diaduk hingga homogen. Adonan kemudian dikukus selama \pm 45 menit, dan dinginkan pada suhu kamar (28-30 $\left.{ }^{0} \mathrm{C}\right)$. Sampel tempe pasta yang telah jadi kemudian dimasukkan ke dalam 172 kantung HDPE (a) 30 g, yang dikemas di dalam kantung plastik HDPE kemudian dimasukkan kedalam freezer dengan suhu $-15^{\circ} \mathrm{C}$ selama 48 jam. Tempe pasta yang telah beku dipindahkan ke dalam kantung laminasi poliester-alumunium foil-polietilen dan direkat secara vakum $80 \%$, lalu dimasukkan kembali kedalam freezer $15^{\circ} \mathrm{C}$. Tempe pasta yang telah dibekukan tersebut dipindahkan ke dalam box styrofoam yang telah diisi $\mathrm{CO}_{2}$ padat ( $d r y$ ice) berlebih kemudian diiradiasi dengan dosis 10 kGy dan 25 kGy.Pasca iradiasi, tempe pasta dibiarkan tetap berada di dalam box sampai $\mathrm{CO}_{2}$ padat benar-benar habis, kemudian dikeluarkan dan disimpan di dalam suhu kamar. Tempe pasta kontrol (tidak diiradiasi) disimpan di dalam freezeryang digunakan untuk pengamatan, dan sebagian lagi disimpan pada suhu kamar untuk pengamatan visual terhadap tingkat kerusakannya apabila disimpan pada suhu $28-30{ }^{\circ} \mathrm{C}$ ).

\section{Proses Radiasi}

Sumber radiasi gamma yang digunakan yaitu Cobalt-60 dengan aktivitas sebesar 11,233 KCi (2012), di fasilitas Iradiator Karet Alam (IRKA) PATIR-BATAN Pasar Jumat, Jakarta. Sampel masing-masing diiradiasi dengan dosis minimum $10 \mathrm{kGy}$ dan $25 \mathrm{kGy}$.

\section{Pengujian Mutu Tempe Pasta}

Pengujian dilakukan berdasarkan metode yang telah dibakuan dan berdasarkan standar nasional Indonesia. Parameter uji meliputi Penetapan kadar air, nilai $\mathrm{pH}$, kadar protein kasar, viskositas, dan bilangan peroksida masingmasing dilakukan berdasarkan Standar Nasional Indonesia ${ }^{(8)}$, kadar malonaldehida diukur berdasarkan hasil reaksi MDA-TBA ${ }^{(9)}$, kapasitas anti oksidan ${ }^{(4)}$, dan kadar isoflavon genestine (10).

\section{Analisis data}

Data yang diperoleh dari hasil pengujian parameter mutu kemudian dianalisa berdasarkan analisa varian (ANOVA) dan uji beda nyata terkecil ${ }^{(11)}$.

\section{HASIL DAN PEMBAHASAN}

\section{Penetapan kadar air ${ }^{(8)}$}

Jumlah air yang terkandung dalam sampel tempe pasta perlu diketahui 
sebagai salah satu parameter yang diperlukan untuk melihat mutu dari produk makanan. Metode yang dilakukan adalah metode susut pengeringan pada suhu $105^{\circ} \mathrm{C}$, karena selama pengeringan diperkirakan tidak hanya air yang menguap, namun ada zat lain, terutama zat-zat yang mudah menguap. Hasil pengamatan susut pengeringan pada tempe pasta disajikan pada Tabel 1. Tabel berikut membuktikan bahwa perlakuan iradiasi gamma dengan dosis sampai 25 kGy dan waktu simpan tidak berpengaruh secara nyata pada susut pengeringan sampel yang diamati. Tetapi, pada sampel selama penyimpanan 6 dan 12 minggu, terdapat perbedaan bermakna antara tempe pasta baik yang tidak diiradiasi (kontrol) dengan tempe pasta maupun sampel yang diiradiasi dengan dosis $10 \mathrm{kGy}$ dan 25 kGy. Hasil yang sama telah ditunjukkan pulapada penelitian tempe pasta sebelumnya ${ }^{(12)}$. Dilaporkan pula bahwa hasil uji sterilisasi komersial pada tempe pasta yang diiradiasi pada dosis $25 \mathrm{kGy}$ telah bebas dari mikroba pembusuk dan mikroba patogen sedangkan mikroba berspora dapat dieliminasi pada dosis 45 kGy ${ }^{(12,13)}$. Hal tersebut menunjukkan bahwa sebagai proses non termal, iradiasi tidak menaikkan suhu bahan yang disinari, demikian pula jenis bahan dan teknik pengemasan terseleksi dapat cukup aman, karena tidak ditemukan kebocoran.

\section{Nilai $\mathbf{p H}^{(8)}$}

Nilai $\mathrm{pH}$ dipengaruhi oleh adanya ion $\mathrm{H}^{+}$dan $\mathrm{OH}^{-}$yang ada di dalam sampelterutama asam amino dan asam lemak merupakan senyawa yang bersifat asam maupun basa. Senyawa protein bila terurai akan melepaskan senyawa-senyawa yang cenderung bersifat basa, diantaranya urea dan ammonia, sedangkan lemak bila terurai akibat oksidasi akan menghasilkan senyawa keton yang bersifat asam ${ }^{(14)}$.

Tabel tersebut menunjukkan bahwa tidak terjadi perubahan $\mathrm{pH}$ secara nyata antara tempe pasta yang tidak diiradiasi (kontrol) dengan tempe pasta yang diiradiasi, karena nilai $\mathrm{pH}$ pada

Tabel 1. Pengaruh iradiasi gamma dan masa simpan pada susut pengeringan tempe pasta.

\begin{tabular}{|c|c|c|c|}
\hline \multirow{2}{*}{ Dosis ( kGy) } & \multicolumn{3}{|c|}{ Susut pengeringan (\%) } \\
\cline { 2 - 4 } & 0 & 6 & 12 \\
\cline { 2 - 4 } & 0 & $24,26 \pm 0,35^{\mathrm{a}}$ & $24,08 \pm 0,01^{\mathrm{a}}$ \\
\hline 0 & $24,43 \pm 0,43^{\mathrm{a}}$ & $23,99 \pm 0,04^{\mathrm{b}}$ & $23,84 \pm 0,20^{\mathrm{b}}$ \\
\hline 10 & $23,58 \pm 0,25^{\mathrm{b}}$ & $23,70 \pm 0,04^{\mathrm{c}}$ & $23,44 \pm 0,30^{\mathrm{c}}$ \\
\hline 25 & $24,09 \pm 0,35^{\mathrm{c}}$ & 23,70 pan ( minggu ) \\
\hline
\end{tabular}

Keterangan : Apabila terjadi perbedaan yang nyata ditandakan dengan huruf yang berbeda, dengan tingkat kepercayaan $95 \%(\alpha=0,05)$. 
Tabel 2. Pengaruh iradiasi gammadan masa simpan pada nilai $\mathrm{pH}$ tempe pasta

\begin{tabular}{|c|c|c|c|}
\hline \multirow{2}{*}{ Dosis (kGy) } & \multicolumn{3}{|c|}{ Masa simpan ( minggu ) } \\
\cline { 2 - 4 } & 0 & 6 & 12 \\
\hline 0 & $7,05 \pm 0,01^{\mathrm{a}}$ & $7,09 \pm 0,01^{\mathrm{a}}$ & $7,04 \pm 0,03^{\mathrm{a}}$ \\
\hline 10 & $6,74 \pm 0,02^{\mathrm{b}}$ & $6,74 \pm 0,02^{\mathrm{b}}$ & $6,74 \pm 0,01^{\mathrm{b}}$ \\
\hline 25 & $6,53 \pm 0,04^{\mathrm{c}}$ & $6,54 \pm 0,01^{\mathrm{c}}$ & $6,58 \pm 0,01^{\mathrm{c}}$ \\
\hline
\end{tabular}

Keterangan :Apabila terjadi perbedaan yang nyata ditandakan dengan huruf yang berbeda, dengan tingkat kepercayaan $95 \%(\alpha=0,05)$

penyimpanan 0,6 , dan 12 minggu tidak jauh berubah atau relatif stabil. Hal ini menunjukkan bahwa iradiasi tidak berpengaruh nyata terhadap nilai $\mathrm{pH}$ sampel yang diamati.

\section{Kadar protein ${ }^{(8)}$}

Pada penelitian ini protein ditetapkan dengan metode semi mikro Kjeldahl.Protein dalam bahan pangan terdiri dari berbagai asam amino yang mengandung senyawa tiol, serta asam amino aromatik dan alifatik.Perlakuan iradiasi terhadap protein, dapat menyebabkan terjadinya deaminasi, dekarboksilasi, oksidasi gugus $\mathrm{S}-\mathrm{H}$, reduksi gugus $\mathrm{S}-\mathrm{S}$, perubahan rantai samping asam amino dan penambahan/ pengurangan rantai peptida. Pada radiolisis protein juga terbentuk berbagai senyawa yang dapat mempengaruhi sifat organoleptik bahan pangan, yaitu $\mathrm{NH}_{3}$, $\mathrm{H}_{2} \mathrm{~S}$, metilmerkaptan, dimetildisulfida, metilsulfida.Peruraian ini diikuti dengan berubahnya sifat protein misalnya sifat biologis, biokimia, dan sifat fisikokimia Pengaruh iradiasi terhadap perubahan komponen protein pangan bergantung pada kondisi ,iradiasi, dan struktur atau karakteristika kimia protein itu sendiri, yang dapat diditeksi dengan metode kromatografi.

Hasil pengamatan kadarprotein total disajikan pada Tabel 3 yang menunjukkan bahwa meskipun terjadi kecendrungan bahwa kadar protein dari sampel yang diiradiasi lebih rendah dari kontrol, namun dari uji statistik menunjukkan bahwa tempe pasta yang diiradiasi tidak mengalami penurunan yang nyata bila dibandingkan dengan kontrol. Metode analisa yang diterapan ini hanya untuk mendapatkan informasi awal, yaitu pada saat destruksi senyawa $\mathrm{N}$ organik baik protein, asam amino maupun hasil metabolism seperti urea pada sampel dapat diubah semua menjadi $\mathrm{N}$ anorganik dalam bentuk garam ammonium sulfat.

\section{Viskositas $^{(8)}$}

Viskositas atau kekentalan merupakan faktor yang penting dari penelitian terhadap tempe pasta ini karena nantinya tempe pasta ini diberikan pada pasien yang terpasang NGT. Viskositas yang diharapkan ialah viskositas dari tempe 
pasta yang dapat melewati selang NGT dengan mudah, cukup dengan bantuan sonde atau suntikan, dan dengan sifat alir yang dapat mengalir setelah tempe pasta diberikan melalui sonde atau suntikan tanpa ada partikel tempe pasta yang tersisa atau tertinggal di dalam selang NGT. Nilai viskositas tempe pasta ditentukan berdasarkan hasil perkalian antara hasil pembacaan dengan alat viskosimeter dengan faktor pengenceran. secara pada sampel tempe pasta dengan cara pengenceran menggunakan air yang telah dididihkan dan didinginkan dengan perbandingan 1 : 1 . Hasil pengamatan viskositas pada tempe pasta disajikan pada Tabel 4.Data tersebut menunjukkan nilai viskositas antara sampel tempe pasta yang diiradiasi dengan kontrol tidak berbeda jauh atau relatif stabil, namun setelah dilakukan pengenceran, terdapat perbedaan bermakna antara tempe pasta yang diiradiasi dengan kontrol. Hal ini menunjukkan bahwa iradiasi tidak berpengaruh terhadap nilai viskositas.Homogenitas partikel sampel selama pengamatan dapat mempengaruhi pengukuran nilai viskositas.

Sedangkan pada pembuatan tempe pasta ini tidak diberi bahan tambahan (homogenizer) apapun yang dapat mendispersikan padatan dalam larutan. Apabila dilihat dari penyimpanan 0 sampai 12 minggu, meskipun demikian,

Tabel 3. Pengaruh iradiasi gamma dan masa simpan pada kadar protein (\%) tempe pasta

\begin{tabular}{|c|c|c|c|}
\hline \multirow{2}{*}{ Dosis (kGy) } & \multicolumn{3}{|c|}{ Masa simpan (minggu) } \\
\cline { 2 - 4 } & 0 & 6 & 12 \\
\hline 0 & $34,06 \pm 0,03^{\mathrm{a}}$ & $33,48 \pm 0,38^{\mathrm{a}}$ & $29,95 \pm 5,86^{\mathrm{a}}$ \\
\hline 10 & $33,78 \pm 0,20^{\mathrm{b}}$ & $32,885 \pm 1,32^{\mathrm{b}}$ & $29,40 \pm 5,79^{\mathrm{b}}$ \\
\hline 25 & $33,405 \pm 0,08^{\mathrm{c}}$ & $32,835 \pm 0,09^{\mathrm{c}}$ & $33,28 \pm 2,40^{\mathrm{c}}$ \\
\hline
\end{tabular}

Keterangan :Apabila terjadi perbedaan yang nyata ditandakan dengan huruf yang berbeda, dengan tingkat kepercayaan $95 \%(\alpha=0,05)$.

Tabel 4. Pengaruh iradiasi gamma dan masa simpan pada nilai viskositas (cp/detik) tempe pasta yang diencerkan dengan air 1:1

\begin{tabular}{|c|c|c|c|}
\hline \multirow{2}{*}{ Dosis (kGy) } & \multicolumn{3}{|c|}{ Masa simpan (minggu) } \\
\cline { 2 - 4 } & 0 & 6 & 12 \\
\hline 0 & 54,3 & 54,2 & 54,4 \\
\hline 10 & 58,9 & 58,4 & 58,2 \\
\hline 25 & 62,9 & 62,1 & 62,4 \\
\hline
\end{tabular}


hasil uji statistik menunjukkan tidak terdapat perbedaan bermakna selama proses penyimpanan.

\section{Bilangan Peroksida ${ }^{(8)}$}

Kerusakan pada lemak nabati adalah teroksidasinya ikatan ganda / ikatan tak jenuh oleh oksigen dari udara yang membentuk senyawa peroksida, sehingga menimbulkan bau tengik yang mengurangi mutu dan estetika produk. Hasil dari seluruh pengamatan terhadap sampel tempe pasta baik pada kontrol dan sampel yang diiradiasi, maupun pada sampel sebelum dan sesudah penyimpanan, bilangan peroksida tidak terdeteksi. Hal ini mungkin disebabkan tempe pasta dikemas di dalam kantung laminasi kedap cahaya dan divakumkan, dan proses radiasi gamma berlangsung dalam kondisi beku sehinggahampir tidak ada oksidasi sampel yang diteliti.

\section{Kadar malonaldehida ${ }^{(9)}$}

Kadar malonaldehida dalam sampel tempe pasta iradiasi perlu diamati karena sebagai indeks ketengikan oksidatif dalam makanan. Kadar tersebut dapat ditetapkan secara spektrofotometri pada panjang gelombang $532 \mathrm{~nm}$ dari senyawa kompleks malondialdehida-tiobarbiturat yang hasilnya dibandingkan dengan kurva larutan standar 1,1,3,3-Tetra Etoksi Propana.Malonaldehida juga dapat diidentifikasi sebagai produk hasil dekomposisi dari asam amino, kompleks karbohidrat, pentose, dan heksosa.Hasil pengamatan kadar malonal-dehida tempe pasta disajikan pada Tabel 5.

Penetapan malonaldehida pada pangan dapat dilakukan sebagai pengukuran tidak langsung pembentukan radikal bebas karena untuk menentukan jumlah radikal bebas secara langsung sangat sulit karena malonaldehida juga sebagai produk yang dihasilkan dari produk sampingan dari biosintesa prostaglandin. Hidroperoksida lipid pada bahan pangan dapat berubah menjadi sejumlah produk toksik seperti aldehid dan malonaldehida yang dapat menyebabkan gangguan pada sel tubuh konsumennya.

Tabel 5. Pengaruh Iradiasi gamma pada kadar malonaldehida (pmol/ml) tempe pasta.

\begin{tabular}{|c|c|c|c|}
\hline \multirow{2}{*}{ Dosis (kGy) } & \multicolumn{3}{|c|}{ Masa simpan (minggu) } \\
\cline { 2 - 4 } & $\mathbf{0}$ & $\mathbf{6}$ & $\mathbf{1 2}$ \\
\hline 0 & $641 \pm 63$ & $752,5 \pm 32$ & $1020 \pm 31$ \\
\hline 10 & $980 \pm 26$ & $1345 \pm 50$ & $1987 \pm 75$ \\
\hline 25 & $1194 \pm 38$ & $1942 \pm 12$ & $2727 \pm 13$ \\
\hline
\end{tabular}


Tabel tersebut menunjukkan bahwa pada sampel yang diiradiasi memiliki kadar malonaldehida yang lebih besar dibandingkan kontrol dari penyimpanan 0 sampai 12 minggu. Hal ini menunjukkanbahwa selama proses iradiasi kemungkinan telah terjadi perubahanpada komponen bahan pangan yang diamati.

Produk pangan tempe pasta memiliki kandungan air, protein dan lemak. Perlakuan iradiasi pada produk pangan dapat menyebabkan beberapa perubahan pada matriks pangan. Selama proses ionisasi yang berlangsung, akan terbentuk hidrogen peroksida yang berasal dari aqueous matriks system pangan meskipun peluang tersebut telah diantisipasi seminimal mungkin. Selama penyimpanan, hidrogen peroksida akan berkurang secara berkala, namun menyebabkan substrat lain dalam bahan pangan teroksidasi. Batas ambang kadar malonaldehida yang diijinkan untuk bahan pangan adalah $5 \mathrm{mg}$ malonaldehida/kg sampel.

Kapasitas anti oksidan ${ }^{(4)}$, dan pengukuran kadar isoflavon genestin ${ }^{(10)}$

Nilai IC50 merupakan nilai untuk menunjukkan aktivitas atau kapasitas dari suatu antioksidan pada bahan pangan. Semakin rendah nilai IC50 maka semakin meningkat aktivitas/kapasitas antioksidannya. Nilai IC50, pada penelitian ini diukur secaraspektrofotometri dengan zat Diphenyl Picryl Hydrazyl (DPPH) yang merupakan radikal bebas stabil, memiliki elektron ganjil dan akan berpasangan dengan atom hidrogen yang disumbangkan senyawa antioksidan. Hasil pengamatan nilai IC50 pada tempe pasta disajikan pada Tabel 6. Tabel tersebut menunjukan bahwa pada perlakuan iradiasi dapat menurunkan nilai IC50 baik sebelum maupun sesudah penyimpanan selama 12 minggu. Minggu ke-0 maupun minggu ke-12 terjadi penurunan nilai IC50 pada kontrol ke dosis iradiasi $10 \mathrm{kGy}$ dan dosis iradiasi 25 kGy, hal ini menunjukkan bahwa selama proses iradiasi terjadi perubahan. Peningkatan nilai kapasitas antioksidan atau nilai IC50 yang menurun pada pengukuran kapasitas antioksidan terbentuknya komponen polifenol.

Tabel 6. Pengaruh iradiasi gamma pada nilai IC 50 ( ppm) tempe pasta.

\begin{tabular}{|c|c|c|}
\hline \multirow{2}{*}{$\begin{array}{c}\text { Dosis } \\
(\mathbf{k G y})\end{array}$} & \multicolumn{2}{|c|}{ Masa simpan (minggu) } \\
\cline { 2 - 3 } & 0 & 12 \\
\hline 0 & 98 & 93 \\
\hline 10 & 75 & 60 \\
\hline 25 & 67 & 67 \\
\hline
\end{tabular}


Kemungkinan lain terjadinya proses slow release anti oksidan yang terperangkap di dalam matriks; atau sebaliknya, akibat terjadinya dekomposisi antioksidan yang sensitive terhadap perlakuan iradiasi. Telah dibuktikan oleh para peneliti terdahulu yang dilaporkan oleh Pawiroharsono ${ }^{(10)}$ bahwa didalam tempe terdapat senyawa yang berfungsi sebagai antioksidan, antara lain isoflavon aglikon daidzein, genistein, glisitein, dan faktor-II (4,6,7-tri-hidroksi isoflavon). Bobot tempe untuk 1 kemasan tempe pasta yaitu 17,44 g sedangkan bobot total isoflavon aglilkon 26,70 mg/100 g tempe, sehingga bobot total isoflavon aglikon tempe dalam tempe pasta yaitu 4,66 mg/17,44 g tempe atau $4,66 \mathrm{mg} / 30 \mathrm{~g}$ tempe pasta. Pada minggu ke-12 terjadi perubahan nilai $\mathrm{IC}_{50}$ dibanding minggu ke nol, hal ini mungkin disebabkan oleh variasi dari sampel yang digunakan. Nilai $\mathrm{IC}_{50}$ yang di dapat baik dari kontrol maupun yang diradiasi dengan dosis $10 \mathrm{kGy}$ dan 25 kGy memiliki kisaran < 100 ppm, ini menunjukkan bahwa tempe pasta iradiasi diharapkan menjadi sumber antioksidan bioaktif yang dapat dimanfaatkan untuk meningkatkan nutrisi pasien yang menggunakan alat bantu NGT.

Kandungan total isoflavon ini kemungkinan dapat meningkat selama proses iradiasi. sehingga kapasitas antioksidan tempe pasta yang diiradiasi dosis $10 \mathrm{kGy}$ dan $25 \mathrm{kGy}$ lebih besar dibandingkan dengan tempe pasta yang diiradiasi. Isoflavon genestein merupakan salah satu jenis isoflavon yang merupakan antioksidan yang dibutuhkan tubuh untuk menghentikan reaksi pembentukan radikal bebas. Hasil pengamatan kadar isoflavon genestein tempe pasta disajikan pada Tabel 7 . Tabel tersebut menunjukkanbahwa pada minggu ke nol, untuk tempe pasta yang diiradiasi dengan dosis $10 \mathrm{kGy}$ mengalami peningkatan dibandingkan kontrol. Hal ini mungkin disebabkan selama proses iradiasi terjadi peningkatan proses peruraian pada ikatan 0-glikosisik dari tempe pasta sehingga kadar isoflavon genestein tempe pasta yang diiradiasi lebih besar. Pada minggu ke-12, baik pada sampel kontrol maupun sampel yang masing-masing diiradiasi dengan dosis $10 \mathrm{kGy}$ dan $25 \mathrm{kGy}$ kadar isoflavon genestein mengalami penurunan. Hal ini mungkin disebabkan selama penyimpanan terjadi peningkatan peruraian jenis anti oksidan tersebut secara biokimia akibat proses ageing.

\section{KESIMPULAN}

Berdasarkan hasil penelitian dari parameter uji yang diterapkan tersebut dapat disimpulkan bahwa tempe pasta yang dikemas secara vakum di dalam 
Tabel 7. Pengaruh iradiasi gammadan masa simpan pada kadar isoflavon genestein (ppm) tempe pasta

\begin{tabular}{|c|c|c|}
\hline \multirow{2}{*}{ Dosis (kGy) } & \multicolumn{2}{|c|}{ Masa simpan (minggu) } \\
\cline { 2 - 3 } & 0 & 12 \\
\hline 0 & 323 & 180 \\
\hline 10 & 512 & 456 \\
\hline 25 & 471 & 464 \\
\hline
\end{tabular}

kantung laminasi polyester-aluminium foil-LLDPE kemudian masing-masing diiradiasi dengan dosis 10kGy dan 25 kGy mutunya dapat dipertahankan sampai 12 minggu pada suhu kamar $\left(28-30^{\circ} \mathrm{C}\right)$. Meskipun penelitian ini masih dalam taraf penjajagan peluang pemanfaatan tempe pasta untuk makanan pasien rumah sakit imunitas rendah, namun masih perlu diteliti lebih jauh tentang teknis penyajian tempe pasta steril iradiasi melalui NGT dengan tingkat kekentalan tertentu sehingga cairan lebih homogen dan dapat mengalir melalui pipa NGT dengan kecepatan konstan.

\section{UCAPAN TERIMA KASIH}

Ucapan terima kasih disampaikan kepada Dr. dr. Carmen M. Siagian, SpGK, MS dari UKI Jakarta yang telah memberikan ide dan saran terbaik, staf dan operator fasilitas irradiator IRKA di PATIR BATAN atas kerjasama dalam mengiradiasi sampel. Ungkapan terima kasih disampaikan pula khususnya bagi Sdr. Cecep M. Nurcahya beserta staf peneliti kelompok Bahan Pangan Bidang Proses Radiasi, PATIR BATAN Jakarta yang telah membantu kelancaran penelitian ini.

\section{DAFTAR PUSTAKA}

1. B. Lastariwati, (2011) Bentuk Makanan Standar Rumah Sakit, diambil dari http://www.wordpress.com

2. L. Aninag, (2011) Nasogastric Tube, diambil dari http://www.wordpress.com

3. Anonim, (2011) Wikipedia Indonesia: Tempe, Ensiklopedia Bebas Berbahasa Indonesia (serial online) diambil dari http://id.wikipedia.org/wiki/Tempe

4. P. Molyneux, "The Use of the Stable Free Radical Diphenylpicryl Hydrazyl"

5. (DPPH) for Estimating Antioxidant Activity", (2004) J. Sci. Technol., Vol. 26, no. 2, p. 211-219

6. T. Murini, (2003) "Obat Jerawat Topikal dan Bentuk Sediannya yang Beredar di Indonesia", J. Kedokteran Yarsi Vol. 11, No. 2, hal.104-110

7. A. Puspita, (2012) "Pengaruh iradiasi gamma terhadap kualitas tempe pasta sebagai makanan pasien yang terpasang Naso Gastric Tube (NGT)", 
Skripsi, Fakultas Farmasi, Universitas Pancasila, Jakarta

8. A. Firmansah, (2009) Peran Medium Chain Triglycerides (MCT) dalam Metabolisme Manusia dan Aplikasi Klinis, J. Kedokteran UNPAD, Vol. 10, No. 03

9. Standar Nasional Indonesia, (2007) Cara Uji Makanan dan Minuman, SNI 01-2891-2007, Jakarta, Dewan Standarisasi Nasional, hal. 3, hal. 79,12, hal.18-20,dan hal.27

10. M.L. Seligman, E.S. Flamm, B.D. Goldstein, R.G. Poser, H.B. Demopoulos and J. Ransohoff, (1977) Spectrofluorescent Detection of Malonaldehyde as a Measure of Lipid Free Radical Damage in Response to Ethanol Potentiation of Spinal Cord Trauma, Journal of Lipids, Vol. 12, No. 11 , p. 945-950.

11. S. Pawiroharsono, (2001) Prospek dan Manfaat Isoflavon untuk Kesehatan, Direktorat Teknologi Bioindustri, Badan Pengkajian dan Penerapan Teknologi, hal. 4-12

12. R.G.D. Steel, and J.H. Torrie, (1980) Prinsip dan prosedur statistika, Suatu pendekatan biometric, Terjemahan oleh: Bambang Sumantri, PT. Gramedia, Jakarta

13. R. Desyana, (2010) Pengaruh iradiasi gamma dosis tinggi terhadap kualitas tempe pasta dan kandungan senyawa isoflavon genestein, Skripsi, Fakultas Farmasi, Universitas Pancasila, Jakarta

14. Z. Irawati, R. Desyana, dan C.M. Siagian, (2011) "Potensi radiasi pengion untuk meningkatkan keamanan, mutu dan gizi tempe pasta. Prosiding Seminar Nasional "Pencitraan dan Pengembangan Produk Lokal Berbasis Kedelai", Fakultas Sains dan Matematika,
Univresitas Kristen Satya Wacana, Salatiga, hal. 18-24.

15. P. Hardjasasmita, (2002) Ikhtisar biokimia dasar, Balai Penerbit Fakultas Kedokteran Universitas Indonesia Jakarta, hal. 51 